Jost Gippert

\title{
Identifying Fakes: Three Case Studies with Examples from Different Types of Written Artefacts
}

\begin{abstract}
This article addresses the question of how to judge the authenticity of different types of written artefacts with different analytical methods. After discussing the reception history of a highly disputed inscribed object, the Praeneste Fibula, the case of hitherto unpublished leather 'cigarillos' from the Near East that are inscribed in an unknown script and language is presented as an example of the interplay of linguistic and philological methods and those of the natural sciences. The third topic is a slate sherd from Dagestan bearing the alphabet of the Caucasian Albanian script, which may be taken as a classic example of a selfrevealing fake.
\end{abstract}

Written artefacts are the most important material basis of all for comparative linguistics, given that they bear the 'tangible' manifestations of historical states of languages and language change that may otherwise only be hypothesised or reconstructed theoretically. Under these premises, the authenticity of such artefacts is of extreme importance when it comes to their scholarly exploitation, and faked witnesses to the past may have a disastrous impact, not only on linguistic reasoning, but also beyond. Three different sample cases with which I have personally been confronted during my career as a comparative linguist will be sufficient to show how methods from different disciplines can yield different results that need to be balanced and aligned with each other to obtain a clearer picture of the historical 'truth'. ${ }^{1}$

\footnotetext{
1 A preliminary German version of this article was printed under the title of 'Der Fälschung auf der Spur. Inschriften und Handschriften unter der Lupe' on the occasion of the centenary of Goethe University, Frankfurt (Main) in a freely distributed leaflet called 'Original, Adaption, (Ver-)Fälschung' edited by Iwo Amelung (2014).
}

Ә Open Access. (C) 2020 Jost Gippert, published by De Gruyter. (cc)BY-NC-ND This work is licensed under the Creative Commons Attribution-NonCommercial-NoDerivatives 4.0 International License.

https://doi.org/10.1515/9783110714333-012 


\section{The Praeneste Fibula}

MANIOS MED FHEFHAKED NVMASIOI - 'Manius made me for Numerius'. When I graduated in Comparative Linguistics in the 1970s, this inscription, engraved in rather clumsy letters running from right to left on a golden brooch (see Figs 1ad), ${ }^{2}$ was considered the oldest Latin text ever to have been preserved for posterity. The inscription was tentatively dated to the seventh century BCE owing to its linguistic characteristics - the nominative ending -OS instead of later -us, the dative ending -OI instead of later $-\bar{o}$, the intervocalic $\mathrm{S}$ in NVMASIOI instead of later $r$, the pronoun MED with a final D instead of later $m \bar{e}$ and, especially, the reduplicated perfect form FHEFHAKED, 'he made', instead of later feecit; in addition to that, it shows archaic-looking letter forms including the spelling FH for the sound $f$. What a disappointment for comparative linguists like me, then, when the Italian epigraphist Margherita Guarducci published extensive work in 1980 proving that the inscription on the brooch, which is usually called the Praeneste Fibula on account of its origin (today's Palestrina, approximately $40 \mathrm{~km}$ east of Rome), is, in fact, a forgery from the late nineteenth century CE jointly produced by its discoverer, the German archaeologist and deputy director of the German Archaeological Institute in Rome, Wolfgang Helbig, and the antique dealer Francesco Martinetti, a friend of his. ${ }^{3}$ Guarducci's reasoning was based on various suspicions, some of which had previously been expressed by other scholars as well, such as contradictory statements by Helbig on the place and date of the

2 For some excellent colour photographs of the brooch and its details, see Mangani 2011-2014, 3-6 and Ferro 2011-2014, 54, 61, 64-65.

3 Guarducci 1980. The discovery was first reported by W. Helbig at a working session of the Roman Section of the German Archeological Institute on 7 January 1887. The report was published in the first issue of the Institute's Mittheilungen in the same year (Helbig 1887), followed by a first transcription and interpretation by Ferdinand Dümmler $(1887,40)$, which also included the first drawing of the fibula, shown here in Fig. 1b. A short account of the session including Dümmler's transcription appeared in Wochenschrift 1887, 121-122 (vol. 4, issue no. 4, 26 January) before the Mittheilungen were printed (anonymously, but not necessarily written by Helbig himself as some have assumed, e.g. Gordon 1975, 2), and Wilhelm Deecke published remarks concerning graphical questions in issue no. 7 of the Wochenschrift (16 February 1887, $220)$, which Dümmler then replied to $(1887,43)$. In another quick reaction, the next issue of the Mittheilungen included a letter to Helbig by Giacomo Lignana, who was the first scholar to raise doubts as to the authenticity of the brooch (Lignana 1887, 139). The very first mention of the brooch and its inscription is found in a letter of Helbig's to Theodor Mommsen on 1 January 1887 (published in Buonocore 2011-2014, 76 along with a facsimile of it on pp. 77-80). 
find. ${ }^{4}$ Above all, however, the author applied methods of scientific analysis for the first time that suggested that the fibula could not possibly be an authentic artefact from the seventh century BCE and that the inscription must have been engraved by a 'modern' forger who was not very skilled at such work - probably Helbig himself.

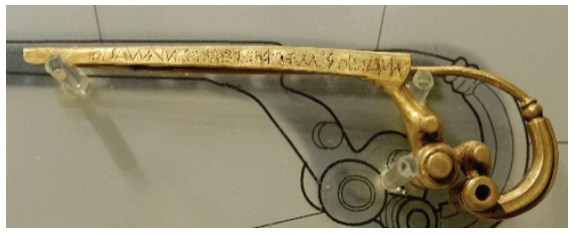

Fig. 1 a: The Praeneste Fibula, housed in the Museo Preistorico Etnografico Luigi Pigorini in Rome.

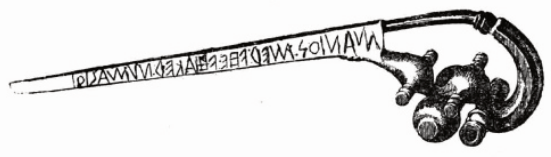

Fig. 1b: Same, drawing from 1887 (first publication).

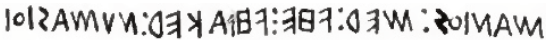 \\ Manios: med: fhe : Fhaked : Numasioi, das heifst Monius me fecit Numerio.}

Fig. 1d: Same, sketch from 1887 (first publication).

Fig. 1c: Same, inscription.

4 According to Helbig's own report, the fibula was acquired by an unnamed 'friend of his' in Palestrina as early as 1871 . Helbig indicated neither the date nor the place where it was found, but assumed it was in a 'tomb' from the sixth century BCE that might have belonged to the same 'stratum' as the Tomba Bernardini, also called the 'tesoro di Palestrina', which was discovered in 1876 (Helbig 1887, 38). In 1900, Georg Karo, another German archeologist, stated in a letter to the director of the Museo Nazionale Preistorico Etnografico 'Luigi Pigorini' in Rome that Helbig himself had told him that Martinetti the antiquarian had bought the fibula from the head of the excavations of the Tomba Bernardini. This letter, first published by F. Zevi $(1976,50)$ and more recently by E. Mangani with some amendments and a facsimile (2011-2014, 24-25 with Fig. 3), had the effect that Helbig's published account was rendered doubtful. Yet even though the acquisition was now under suspicion of being illegal, the authenticity of the fibula was actually supported by this rather than contradicted by it. See Gordon 1975, Ridgway 1977 and Wieacker 1984 for more detailed discussions on the question of the provenance and authenticity of the brooch. 
Guarducci's publication split academia into two groups, those convinced and those unconvinced, thus making the fibula unusable for linguistic reasoning until about 30 years later when the tide turned again. In 2011, the Italian scientists Daniela Ferro and Edilberto Formigli presented the results of new physical and chemical investigations they had undertaken with a scanning electron microscope. ${ }^{5}$ Among other things, the analysis revealed microcrystallisations on the engraved surface, which in their view clearly demonstrated that the brooch itself and the inscription on it are genuine. Thus, comparative linguists can finally use the inscription again, and there is no longer any need to interpret FHEFHAKED as 'faked'.

\section{Cigarillos from the Levant}

The eventful reception history of the Manios brooch is by no means an isolated case. Scepticism about the authenticity of written artefacts is not restricted to inscriptions on stone, metal, wood, bone or other 'hard' materials either, but can also apply to manuscripts (on papyrus, leather, parchment, paper or any other 'soft' writing material). When it comes to unmasking forgeries, comparative linguists are not the only ones who should look at particularly 'sensational' finds with suspicion and seek help from natural scientists. In fact, the natural sciences employ a wide range of methods today that can be used to check the authenticity of an 'old'-looking document. At the Institute for Empirical Linguistics in Frankfurt, we have been faced with a relevant case for about twenty years now that is well suited to illustrate this point.

Sometime during the summer of 1998, we received a visit from a very polite English-speaking young man who introduced himself as an employee of an international airline and asked me whether we were well versed in old writing. 'Well,'

\footnotetext{
5 The discovery was presented at a special conference devoted to the fibula at the Luigi Pigorini National Museum of Prehistory and Epigraphy on 6 June 2011 and was first reported on by D. F. Maras (2012) in a journal called Etruscan News. Ferro's and Formigli's presentation was only published in 2015, however, together with nine other conference papers that appeared in volume 99 of the Bullettino di Paletnologia Italiana (see Ferro and Formigli 2011-2014).

6 See Ridgway 1977 for this allusion. As a matter of fact, there was much debate about the authenticity of the inscription on purely linguistic grounds, beginning with Lignana (1887). Personally, I remember discussing it for the first time with Eric Hamp during his stay in Berlin in 1981 (Hamp 1981, 151). For a comprehensive bibliography up to 2011, see Mangani 2011-2014, $30-41$.
} 
I replied, 'not in everything, but quite well-versed in some types of writing. What kind of thing have you got in mind?' He immediately took a rolled-up artefact from his wallet that was about $10 \mathrm{~cm}$ long and strongly reminiscent of a cigarillo, but which was obviously made of leather rather than tobacco. The gentleman carefully opened it at one of the corners, and there were written characters on the inside. 'This is certainly very interesting,' I said, 'but unless the entire thing is unrolled, we will certainly not be able to determine what it contains. I would also strongly advise you not to unroll it yourself because otherwise the object might get damaged, especially if it's very old. There are specialists for things like this at the State Library in Berlin, for example, who we've been working together with for years. In other words, the item should be sent to Berlin where it can be unrolled professionally and prepared for reading in a suitable form before we can say anything more about it.' - 'I'll have to obtain permission first in that case,' the guest admitted before he left us. My question about the exact origin and ownership of the artefact remained unanswered; from what he told me about it, I could only gather that it came from the eastern Mediterranean (Israel, Palestine, Jordan or Lebanon) and had belonged to a private person who had found it in a clay jug on his own estate along with similar objects.

To my great surprise, the young man reappeared a few weeks later; not only had he obtained permission to send the object to Berlin, but he was also carrying a second 'cigarillo'. So I asked Hartmut Ortwin Feistel, head of the Oriental Department of the State Library, ${ }^{7}$ whether the Library's restoration department could scrutinise these finds, and thankfully, he agreed to that immediately. Having no opportunity to go to Berlin himself, the bearer handed one of the objects over to me (he did not want to hear anything about a contract or the like), and I had it taken to Berlin by a trusted person. A few weeks later, the restoration workshop had done its work: ${ }^{8}$ the artefact was now unrolled, and it actually revealed several lines of text on the inside, obviously written from right to left (a few characters even seemed to be written on the outside; see Figs. 2a and 2b). ${ }^{9}$ The script bore a certain resemblance to Semitic scripts of the first pre-Christian millennium, but it was not immediately identifiable with any of these (Canaanite, Moabite, Samaritan, Phoenician or Aramaic $)^{10}$ and therefore was not 'decipherable'.

7 My e-mail to H. O. Feistel, 12 October 1998, 19:17.

8 E-mail from H. O. Feistel, 20 January 1999, 9:19.

9 High-resolution images of the unrolled object taken in Frankfurt; both sides, 2 February 1999. 10 For comparison, see Faulmann 1880, 78-79; Alphabete 1969, 10; Gippert 2010b, for example. 


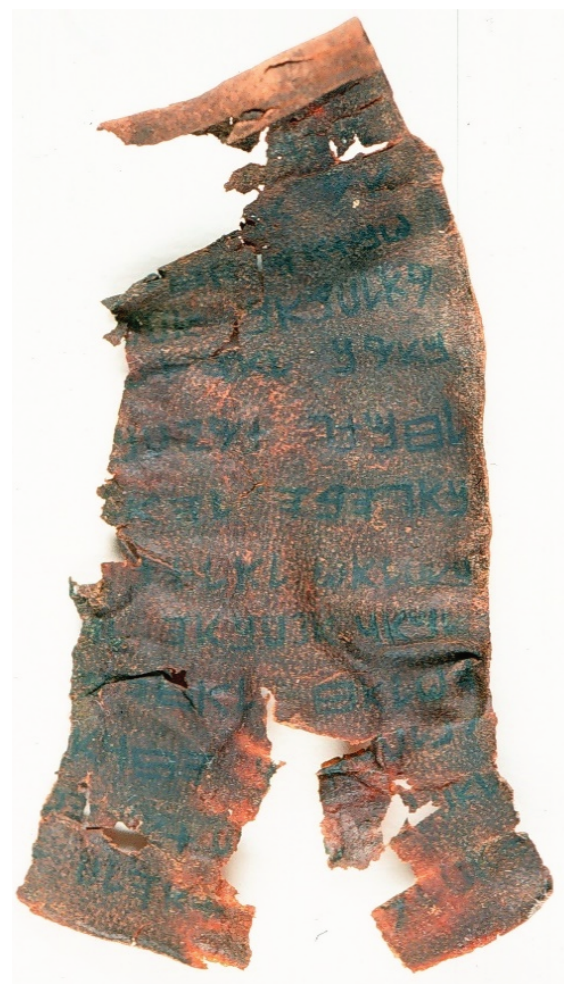

Fig. 2a: ‘Cigarillo’ no. 1, inside.

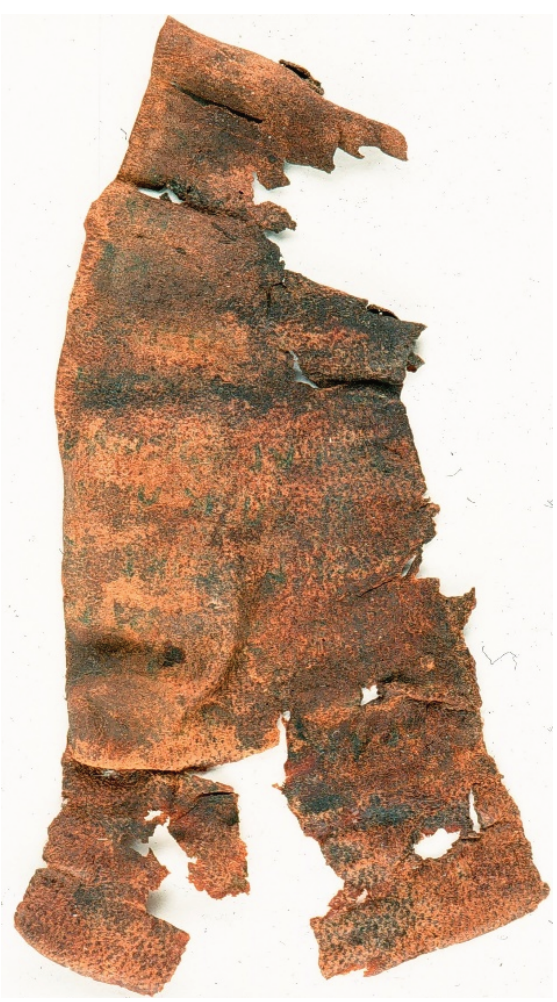

Fig. 2b: Same, outside.

This was not surprising, of course, because the characters were barely recognisable on the dark brown leather background. First of all, it was necessary to improve the visibility of the writing. The State Library had experimented with ultraviolet imaging before, but this did not yield any noteworthy results, except for the suggestion that the ink might be soot-based. ${ }^{11}$ So we tried digital photographic processing in order to enhance the contrast between the brown tint of the leather and the slightly darker tint of the characters, which did, in fact, give us a much clearer picture (see Figs. 3a and 3b). ${ }^{12}$ However, the script was still not

11 E-mail from H. O. Feistel, 20 January 1999, 8:28.

12 Digitally enhanced images of the inside, produced in Frankfurt, 9 February 1999; see <http://titus.uni-frankfurt.de/didact/semit/leather/leather1.htm> (last accessed on 14 May 2020) for an assortment of images of the artefact. 
identifiable, ${ }^{13}$ let alone the content, age or provenance of the document. ${ }^{14}$ On his next visit to Frankfurt, the bearer - who had revealed his name in the meantime, but will remain anonymous here - received an answer from us that was hardly satisfactory: 'Yes, it is a very old-looking inscribed leather fragment, but we don't know any details about it yet'.

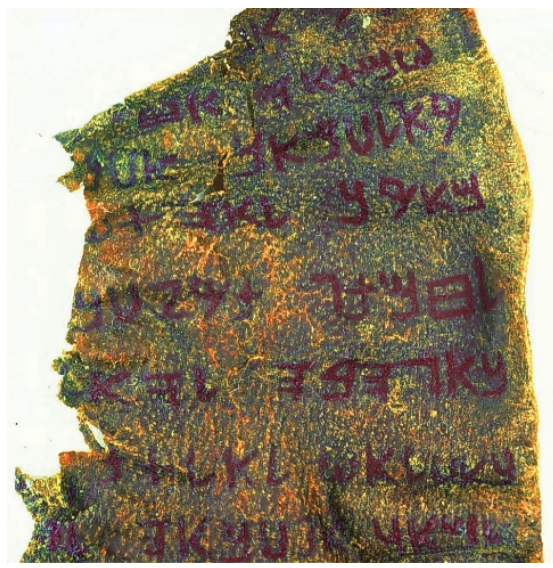

Fig. 3a: 'Cigarillo' no. 1, inside, upper part, processed.

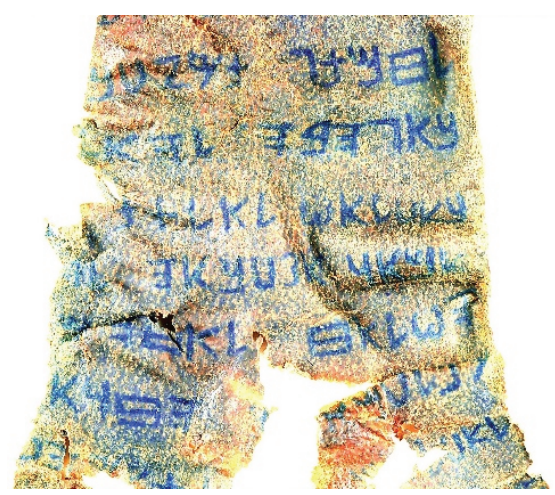

Fig. 3b: Same, lower part, processed.

In order to find out more, I therefore proposed to subject the artefact to radiocarbon analysis (also known as ${ }^{14} \mathrm{C}$ or carbon-14 analysis). ${ }^{15}$ This procedure makes it possible to roughly determine the age of organic material (which includes leather, of course) with an accuracy of between 30 and 100 years, depending on the state of conservation of the object and its degree of contamination by dirt and suchlike; it should at least enable us to determine the authenticity of the object, we thought. The gentleman needed further permission for this, of course, given that $\mathrm{a}^{14} \mathrm{C}$ analysis, which involves determining the decay time of the radioactive carbon content in dead organisms, 'contaminates' itself to a considerable degree:

13 Besides Semitic scripts of the above-named types, 'Hellenoid' alphabets such as Lydian and Lycian (see Faulmann 1880, 168; Gippert 2000a; Lycian 1991-2020; Lydian 1991-2020) or even scripts from ancient Italy (see Gippert 2001; Old Italic 1991-2020) had also been taken into account (my e-mail to H. O. Feistel, 15 January 1999, 18:41).

14 During one of his later visits (on 5 February 1999), the bearer indicated a region approx. 50 km north of the Dead Sea (my e-mail to H. O. Feistel, 8 February 1999, 11:14).

$15 \mathrm{~A}{ }^{14} \mathrm{C}$ analysis was first suggested by H. O. Feistel (e-mail, 18 January 1999, 11:30). 
a piece has to be cut out of the object, about $1 \mathrm{~cm}^{2}$ in size and ideally with no ink on it, which then gets completely destroyed during the analysis, damaging the document forever. ${ }^{16}$ For this reason, the radiocarbon method had rarely been used on original manuscripts in the past - the Berlin State Library employed it for the first time in $2004^{17}$ to determine the temporal stratification of Tocharian manuscripts from the Turfan collection, which extends over nearly the whole of the first millennium $\mathrm{CE}^{18}$

To my surprise, our bearer received the necessary approval again, and he also brought two more 'cigarillos' along with him to have a radiocarbon analysis carried out on them. I helped him to find institutions in Germany and abroad that knew how to use this method. He first intended to go to Zurich (because he had to 'land' there frequently anyway), but in the end he decided on a laboratory in Oxford, ${ }^{19}$ which estimated a time range of five months for the work. In order not to waste the waiting time, the bearer had another one of his 'cigarillos' opened, this time simply by applying undistilled water (!), and had a high-resolution colour scan of it made by Gernot Feucht's team at the Analytical Laboratory at Aventis Research \& Technologies in Frankfurt, ${ }^{20}$ which was kindly lent to us for further processing (see Figs. 4a-c). ${ }^{21}$ Unfortunately, neither the script nor the text disclosed any secrets.

16 See Rabin 2015, 28 as to the difference between 'contaminating' and 'non-destructive' methods of analysis.

17 E-mail from P. M. Grootes to H. O. Feistel and T. Tamai, 27 July 2004: 18:34.

18 Tamai 2011, 370-375.

19 My e-mail to H. O. Feistel, 17 May 1999, 11:54.

20 E-mail from G. Feucht, 4 Oct. 1999, 8:23. Since 2004, Aventis has been part of the SanofiAventis corporation.

21 My e-mail to H. O. Feistel, 14 Oct. 1999, 12:36; see <http://titus.uni-frankfurt.de/didact/ semit/leather/leather2.htm> (last accessed on 14 May 2020). 


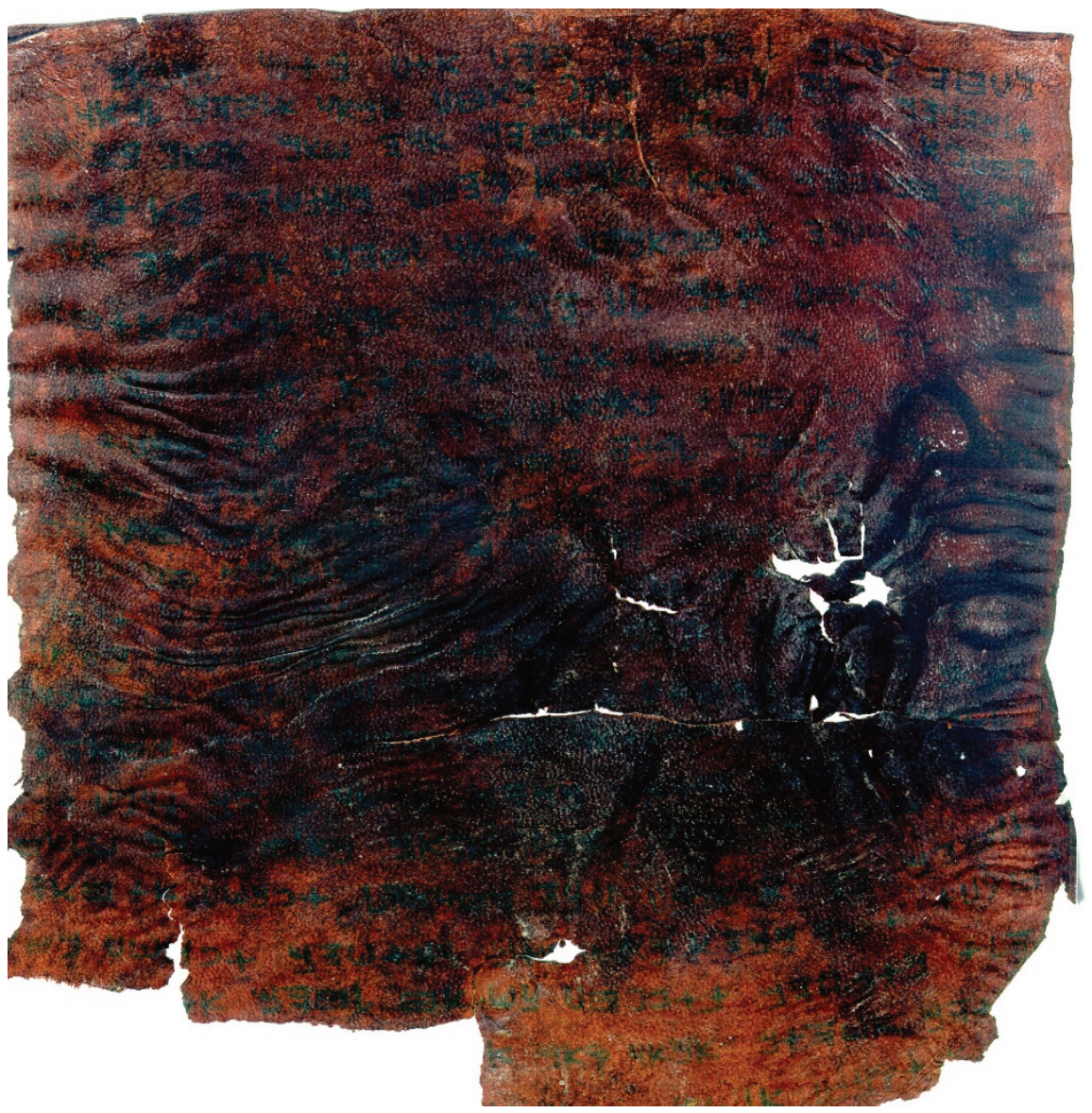

Fig. 4a: Cigarillo no. 2, unrolled, inside.

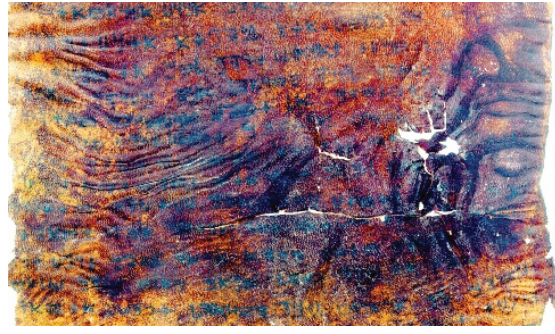

Fig. 4b: Same, excerpt, processed.

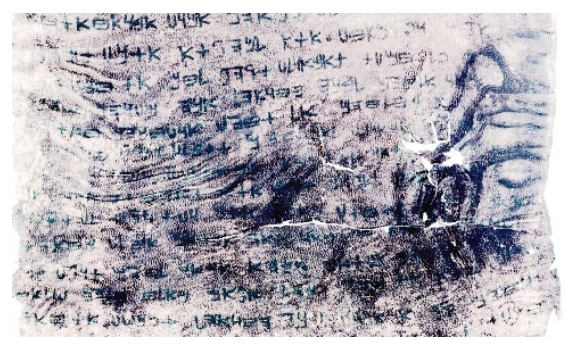

Fig. 4c: Same, processed further. 
More than twenty years have passed since then, in which I have not heard from or seen anything of the polite employee from the unknown airline. I do not want to conclude from this that he had the ${ }^{14} \mathrm{C}$ analysis carried out in Oxford and it revealed that the leather dates from the middle of the twentieth century $\mathrm{CE}$ - which would mean that the lettering cannot be older; perhaps the silence has been for completely different reasons. What has remained, though, is the 'cigarillos' that were unrolled, and I am still eager to solve the question of whether they are 'real' documents from the first millennium BCE - all the more so since the applicable scientific processes have improved considerably meanwhile. In 2013, I handed the 'cigarillos' over to Ira Rabin, a renowned specialist in the material analysis of manuscripts. The first investigation she carried out concerned the ink: with an X-ray fluorescence-based 'Jet Stream M6' instrument, ${ }^{22}$ she was able to show that it is, indeed, soot-based, as previously suggested. As this type of ink was always used in the Near East, however, it unfortunately gives us no further hints as to the date or origin of the artefacts. ${ }^{23}$ Consequently, there seems to be no way round radiocarbon analysis, ${ }^{24}$ which I hope will be performed on them one day to reveal more information.

\section{Why fake a written artefact?}

The question remains: what makes someone fake a written artefact at all? In the case of the Manios fibula, two things were suspected: addiction to profit in the case of Martinetti the antiquarian (the inscription makes the fibula even more valuable than the gold from which it is made), and craving for recognition in the case of Helbig the archaeologist (being acknowledged as the discoverer of the oldest Latin inscription we know of certainly boosted his reputation in the late nineteenth century). In the case of the Near Eastern 'cigarillos', if they are indeed fakes, then the former motive is likely again: interest in pre-Christian manuscripts from the region has risen sharply at least since the discovery of the 'Dead Sea Scrolls' (which, mind you, were also kept in clay jugs), and if provided with

22 For more on the technique and the different sorts of inks and their characteristics, see Rabin 2015, 29-30. The research was funded by the German Research Foundation (DFG) as part of the work done at Collaborative Research Centre 950 ('Manuscript Cultures in Asia, Africa and Europe') and was conducted within the scope of the Centre for the Study of Manuscript Cultures (CSMC) at Hamburg University.

23 E-mail from I. Rabin, 9 Dec. 2013, 19:06.

24 E-mail from I. Rabin, 9 Dec. 2013, 21:36. 
a certificate of authenticity, artefacts like ours are likely to yield a very good price at auctions. Occasionally, there may also be legal or even political motives for creating such fakes: claims of hegemony and possession can readily be derived from a document that is 'back-dated' by five hundred years (as in the case of the so-called 'Donation of Constantine', a document allegedly from the year 315 attributed to Emperor Constantine, which granted extensive rights to the Roman popes and was recognised as a forgery as early as the fifteenth century). ${ }^{25}$ This even applies to the founding charters of entire states (such as the so-called privilegium maius of the Habsburg emperor Rudolf IV, a document from 1358-1359 which considerably expanded the authentic founding document of Austria, the privilegium minus of 1156, from which it was allegedly copied). ${ }^{26}$

Sometimes we may also assume less 'tangible' interests to be involved, as in the case of inscriptions that are used to prove that a people or a language community possesses ancient literacy and is therefore superior to others. ${ }^{27}$ This motive applies to a slate sherd approx. $10 \times 6 \times 1 \mathrm{~cm}$ in size $\mathrm{e}^{28}$ and covered with letters in the alphabet of the so-called 'Caucasian Albanians" ${ }^{29}$ (see Figs. 5a-5d), found in $1970^{30}$ in Upper Labko in Dagestan in the north-eastern Caucasus, ${ }^{31}$ which obviously reproduces the 'Albanian' alphabet list published in 1937 on the basis of an encyclopaedic Armenian manuscript of the thirteenth century (MS 7117, fol. 145rv of the Matenadaran, Yerevan; see Figs. 6a and 6b). ${ }^{32}$ Not only

25 Nicholas of Cusa's treatise De concordantia catholica of 1433 (ch. III, sect. 2; edition from Basel, 1565, 780-783; <http://diglib.hab.de/drucke/413-theol-2f/start.htm?image=00880 > (last accessed on 14 May 2020).

26 See the article by Ira Rabin and Oliver Hahn in Part III of this volume.

27 A similar case may be seen in the Glozel tablets discussed in Catherine Breniquet's article in Part I of this volume.

28 These measurements are stated in Gukasjan 1971, 132.

29 See Gippert 2015 for a brief summary of the written heritage of the Caucasian 'Albanians'.

30 Arslanbekov 1970 and 1971, 70-72. Not much is known about the circumstances of the find. According to Arslanbekov (1971, 70), the sherd was found by 'young local historians' ('юными краеведами') in an 'open field near the village' ('в открытом поле близ селения'); Gukasjan $(1971,130)$ gives the name of the 'students' ('учащиеся') as Arslanbek Arslanbekov, a son of the aforementioned author, and Galina Isabekova. Gukasjan further quotes the historian V[ladimir] G[erasimovič Kotovič for the information that the place in question once bore a 'settlement' ('поселение') in the third-seventh centuries $(1971,130)$.

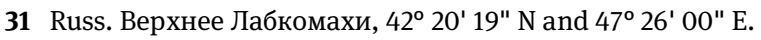

32 The 'Albanian' alphabet is highlighted in the images (which were kindly provided by Arshak Banouchyan, e-mail from 5 May 2010); it is preceded by (the end of) the Old Georgian alphabet and followed by (the beginning of) the Coptic alphabet. The first publication of the list (Šanidze 1938) included greyscale images of the relevant pages with the rubrics re-drawn in red (tables 
can this be deduced from the letter forms, which coincide with those of the alphabet list in nearly every detail, thereby distinguishing them from authentic inscriptions and manuscripts in the same script, ${ }^{33}$ but it can also be seen in the order of the letters, which has obviously been changed by the division of the list into two manuscript pages, with the second page taken first (see Figs. 7a-7f). ${ }^{34}$

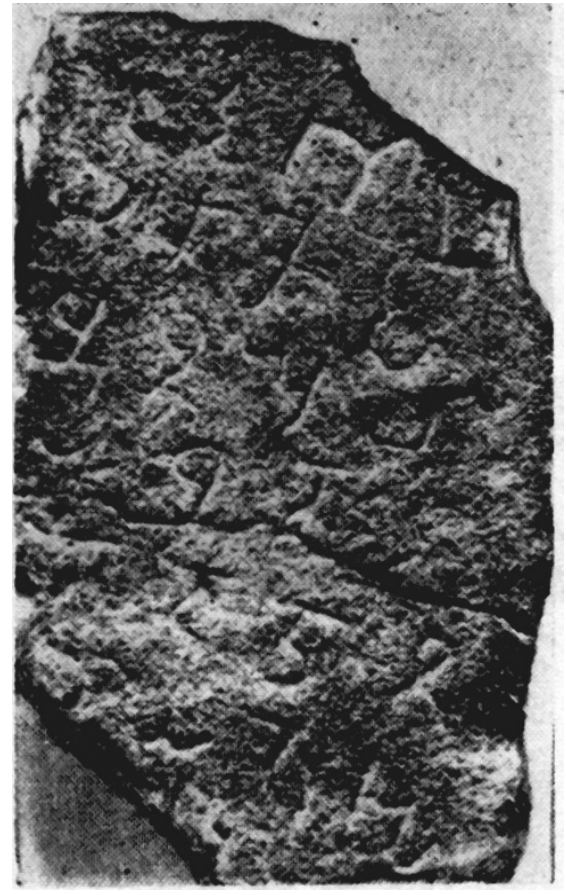

Fig. 5a: The slate from Upper Labko.

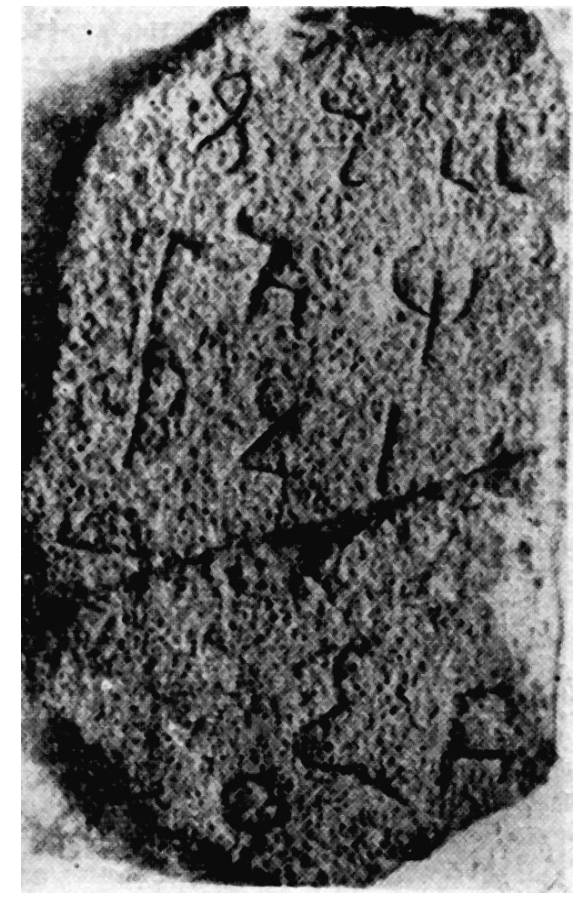

Fig. 5b: Same, rear side.

between pp. 16 and 17); Šanidze 1960 contained a black-and-white reproduction of only the 'Albanian' alphabet (Table 1).

33 See Gippert et al. 2008, II-2-6 where the letters from the alphabet list are compared with those appearing in the only 'Albanian' manuscripts preserved, the palimpsests of St Catherine's Monastery on Mt Sinai.

34 Murav'ev 1986 and Gippert et al. 2008, II-92-93. 


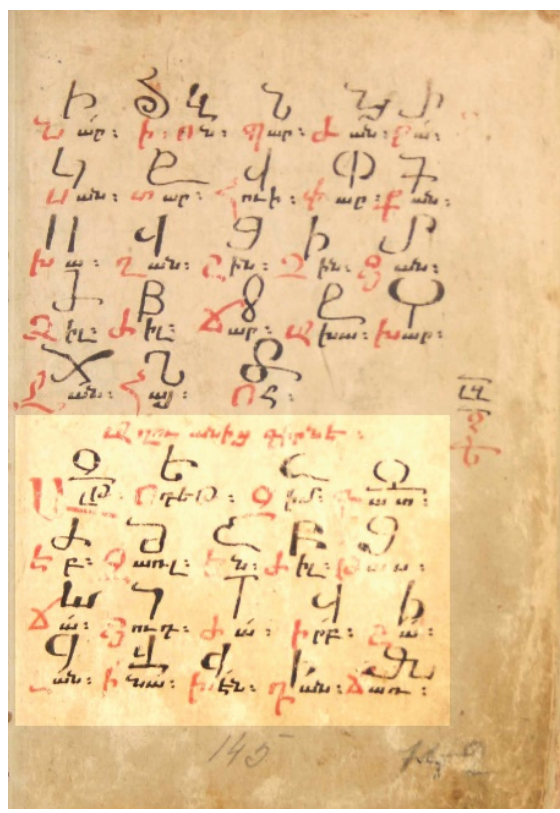

Fig. 6a: Caucasian Albanian alphabet list in ms. Matenadaran 7117, fol. 145 r.

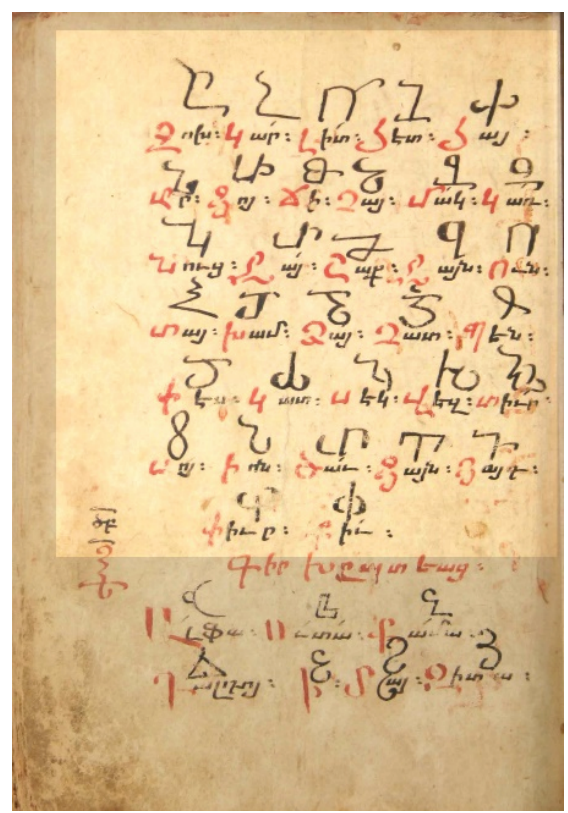

Fig. 6b: Same, continuation on fol. 145v.

As in the latter case, it need not always be scientific analyses that enable us to detect a fake. In many instances, inconsistencies between (paleo)graphical forms, linguistic characteristics and textual content are sufficient to raise concerns or make a forgery seem likely. However, it is particularly the interplay of linguistics, philology, archaeology and 'hard' sciences that promises to yield important new insights into the history of written artefacts and help us identify documents as fakes. We cannot expect every forgery to be uncovered easily, of course, but as the case of the Praeneste Fibula shows, new methods can lead to an increase in our knowledge and put an end to long-lasting debates. 


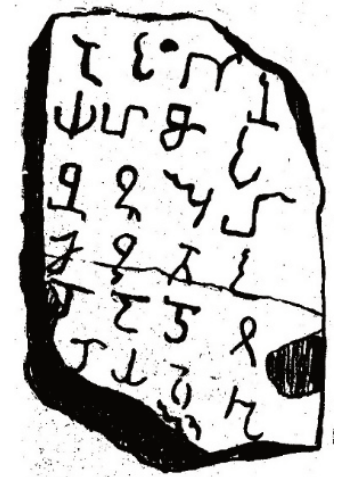

Fig. 7a: The slate from Upper Labko, drawing.

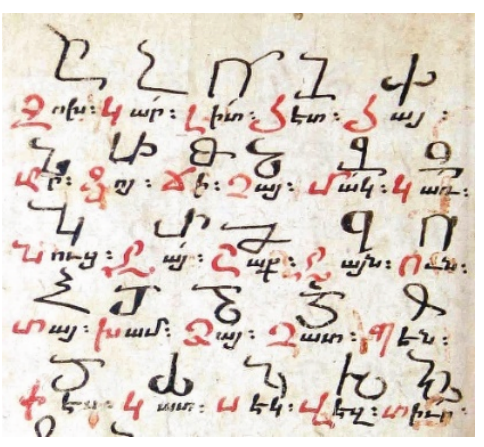

Fig. 7c: Caucasian Albanian alphabet list in ms. Matenadaran 7117, fol. $145 \mathrm{v}$, upper part.

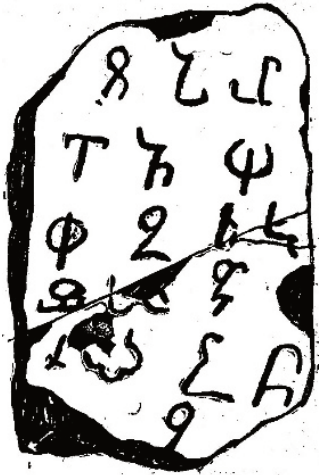

Fig. 7b: Same, rear side.

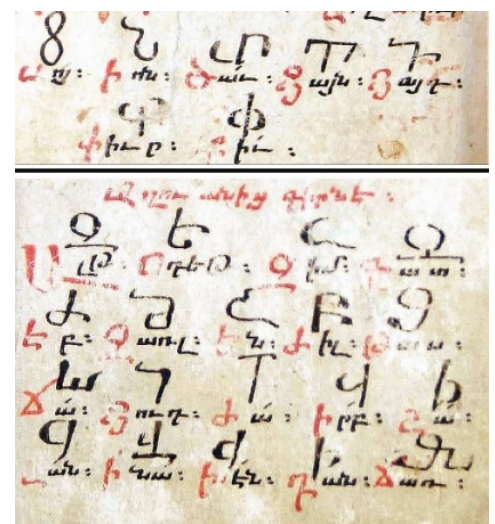

Fig. 7d: Same, continuation on fol. 145v, and beginning on fol. $145 \mathrm{r}$.

Palimpsest characters

Transcription

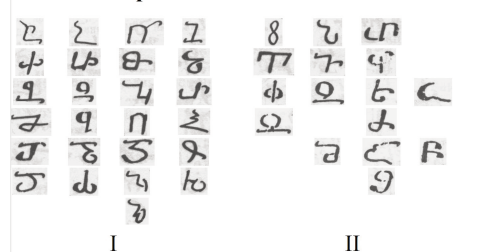

$+\boldsymbol{T}_{3}$

8 U. $Y$

I $U$ g 8 T $7 y$

I. 2 \%

$+26$

d. 9 o- $Z$

$\begin{array}{llll}\mathbf{J} & 6 & \mathbf{S} & \mathbf{9} \\ \boldsymbol{5} & \mathbf{d} & \mathbf{h} & \boldsymbol{1}\end{array}$

S C P

to

I

II

II

Fig. 7e: Characters from the slate contrasted with those appearing in the Caucasian Albanian palimpsests. 


\section{References}

Alphabete und Schriftzeichen des Morgen- und des Abendlandes. Zweite, von Fachwissenschaftlern überarbeitete und erweiterte Auflage. Zum allgemeinen Gebrauch mit besonderer Berücksichtigung des Buchgewerbes. Berlin: Bundesdruckerei / Wiesbaden: Harrassowitz, 1969.

Arslanbekov, X[asbula Magomedovič] (1970), 'Samaja drevnjaja nadpis' Dagestana', in Dagestanskaja pravda 285/14078, Dec. 3 (non vidi).

Arslanbekov, X[asbula Magomedovič] (1971), 'Naxodka v vysšej stepeni cennaja', in Sovetskij Dagestan, 1971/3: 70-72.

Buonocore, Marco (2011-2014), 'Helbig, Mommsen e la Fibula Prenestina: una settimana prima della presentazione ufficiale del 7 gennaio 1887', in Giornata di Studio sulla Fibula Prenestina, 73-82.

Deecke, Wilhelm (1887), 'Bemerkungen zu den Inschriften in No. 4, S. 120 f.', in Wochenschrift für Klassische Philologie, 4: 220.

Dümmler, Ferdinand (1887), 'Iscrizione della Fibula Prenestina', in Mittheilungen des Kaiserlich Deutschen Archaeologischen Instituts, Roemische Abtheilung / Bullettino dell' Imperiale Istituto Archeologico Germanico, Sezione Romana, 2: 40-43.

Faulmann, Carl (1880), Das Buch der Schrift, enthaltend die Schriftzeichen und Alphabete aller Zeiten und aller Völker des Erdkreises, second edition, Vienna: Hof- und Staatsdruckerei (reprinted in Nördlingen: Greno, 1985).

Ferro, Daniela and Edilberto Formigli (2011-2014), 'Risultati delle recenti indagini archeometriche sulla Fibula di Manios', in Giornata di Studio sulla Fibula Prenestina, 4371.

Giornata di Studio sulla Fibula Prenestina, Roma, 6.6.2011 = Bullettino di Paletnologia Italiana, 99 (2011-2014 [2015]).

Gippert, Jost (2000a), Die 'helleniden' anatolischen Alphabete, PDF, 29.10.2000: 〈http://titus.uni-frankfurt.de/didact/idg/anat/angrschr.pdf>(last accessed on 14 May 2020).

Gippert, Jost (2000b), The Development of Semitic Alphabets, PDF, 17.12.2000: 〈http://titus.uni-frankfurt.de/didact/idg/iran/npers/arabalpx.pdf〉 (last accessed on 14 May 2020).

Gippert, Jost (2001), The Development of Alphabets in Ancient Italy (extended), PDF, 14.1.2001: <http://titus.uni-frankfurt.de/didact/idg/ital/italalpx.pdf>(last accessed on 14 May 2020).

Gippert, Jost (2015), 'Caucasian Albanian manuscripts', in Alessandro Bausi et al. (eds), Comparative Oriental Manuscript Studies. An Introduction, Hamburg: COMSt, 43.

Gippert, Jost, Wolfgang Schulze, Zaza Aleksidze, and Jean-Pierre Mahé (2008), The Caucasian Albanian Palimpsests of Mount Sinai, vol. 1 (Monumenta Palaeographica Medii Aevi, Series Ibero-Caucasica 2/1). Turnhout: Brepols.

Gordon, Arthur Ernest (1975), The Inscribed Fibula Praenestina. Problems of Authenticity, Berkeley/Los Angeles: University of California Press.

Guarducci, Margherita (1980), 'La cosiddetta Fibula Prenestina: antiquari, eruditi e falsari nella Roma dell'ottocento; con un'appendice di esami e di analisi', in Atti della Accademia Nazionale dei Lincei / Memorie / Classe di Scienze Morali, Storiche e Filologiche 8 ser., 24/4: 415-574. 
Gukasjan, V[orošil] L[evonovič] (1971), 'O novonajdennom spiske albanskogo alfavita', in Sovetskaja Tjurkologija, 1971/2, 130-135.

Helbig, Wolfgang (1887), 'Sopra una fibula d'oro trovata presso Palestrina', in Mittheilungen des Kaiserlich Deutschen Archaeologischen Instituts, Roemische Abtheilung / Bullettino dell' Imperiale Istituto Archeologico Germanico, Sezione Romana, 2: 37-39.

Lignana, G[iacomo] (1887), 'Sopra l'iscrizione della Fibula Prenestina', in Mittheilungen des Kaiserlich Deutschen Archaeologischen Instituts, Roemische Abtheilung / Bullettino dell'Imperiale Istituto Archeologico Germanico, Sezione Romana, 2: 139-140.

Lycian, [Unicode] Range 10280-1029F, PDF: <https://www.unicode.org/charts/PDF/U10280.pdf> (last accessed on 14 May 2020).

Lydian, [Unicode] Range 10920-1093F, PDF: <https://www.unicode.org/charts/PDF/U10920.pdf> (last accessed on 14 May 2020).

Mangani, Elisabetta (2011-2014), 'La Fibula Prenestina: oltre un secolo di discussioni', in Giornata di Studio sulla Fibula Prenestina, 1-41.

Maras, Daniele F[ederico] (2012), 'Scientists declare the Fibula Prenestina and its inscription to be genuine "beyond any reasonable doubt”, in Etruscan News, 14: 1 and 20.

Murav'ev, Sergej [Nikitič] (1986), 'Ostorožno: fal’šivka! (Ob odnom novonajdennom spiske aluanskogo [kavkazsko-albanskogo] alfavita', in Banber Matenadarani, 15: 250-259.

Old Italic, [Unicode] Range 10300-1032F, PDF: 〈https://www.unicode.org/charts/PDF/U10300.pdf〉 (last accessed on 14 May 2020).

Rabin, Ira (2015), 'Instrumental analysis in manuscript studies', in Alessandro Bausi et al. (eds), Comparative Oriental Manuscript Studies. An Introduction, Hamburg: COMSt, 2730.

Ridgway, David (1977), 'Manios Faked?', in Bulletin of the Institute of Classical Studies, 24: 1730 .

Šanidze, Akaki (1938), 'Novootkrytyj alfavit kavkazskix albancev i ego značenie dlja nauki', in Izvestija Instituta Jazyka, Istorii i Material'noj kul'tury im. akad. Marra Gruzinskogo Filiala Akademii Nauk SSSR, 4: 1-62.

Šanidze, Akaki (1960), ‘Jazyk i pis’mo kavkazskix albancev’, in Sakartvelos SSR Mecnierebata Ak'ademiis sazogadoebriv mecnierebata ganq'opilebis moambe / Vestnik otdelenija obščestvennyx nauk Akademii Nauk GSSR, 1: 168-189.

Tamai, Tatsushi (2011), Paläographische Untersuchungen zum B-Tocharischen (Innsbrucker Beiträge zur Sprachwissenschaft 138), Innsbruck: Institut für Sprachen und Literaturen der Universität Innsbruck, Bereich Sprachwissenschaft.

Wieacker, Franz (1984), 'Die Manios-Inschrift von Präneste. Zu einer exemplarischen Kontroverse', in Nachrichten der Akademie der Wissenschaften in Göttingen, PhilologischHistorische Klasse: 373-399.

Zevi, Fausto (1976), 'Un documento inedito sulla fibula di Manios', in Prospettiva, 5: 50-52. 


\section{Figures}

$1 \mathrm{a}$

$1 \mathrm{~b}$

$1 \mathrm{c}$

$1 \mathrm{~d}$

$2 \mathrm{a}, 2 \mathrm{~b}$

$3 a, 3 b$

$4 \mathrm{a}$

$4 \mathrm{~b}, 4 \mathrm{c}$

5a, $5 \mathrm{~b}, 7 \mathrm{a}, 7 \mathrm{~b}$ $6 \mathrm{a}, 6 \mathrm{~b}, 7 \mathrm{c}, 7 \mathrm{~d}$

$7 \mathrm{e}$
Marie-Lan Nguyen (2009), <https://commons.wikimedia.org/ wiki/File:Fibula_Praenestina_Terme_Inv_Museo_Pigorini_ 2819.jpg> (CC Attribution 2.5 Generic, unaltered). Mittheilungen des Kaiserlich Deutschen Archaeologischen Instituts, Roemische Abtheilung/Bullettino dell'Imperiale Istituto Archeologico Germanico, Sezione Romana 1887, 40. Marie-Lan Nguyen (2009), <https://commons.wikimedia.org/ wiki/File:Fibula_Praenestina_Terme_Inv_Museo_Pigorini_ 2819_(main_part).jpg> (CC Attribution-Share-Alike 2.5 Generic, unaltered; last accessed on 14 May 2020).

Wochenschrift für Klassische Philologie 1887, 121.

J. G., 2.2.1999.

J. G., 19.10.1999.

Analytisches Laboratorium of Aventis Research \& Technologies, team led by Dr Gernot Feucht, 4.10.1999.

14.10.1999.

Sovetskij Dagestan 1971/3, 70-71.

Arshak Banouchyan, Matenadaran (Mesrop Mashtots Institute of Ancient Manuscripts), Yerevan (2010); processed by J. G., 9.5.2020.

Gippert et al. 2008, II-93. 
